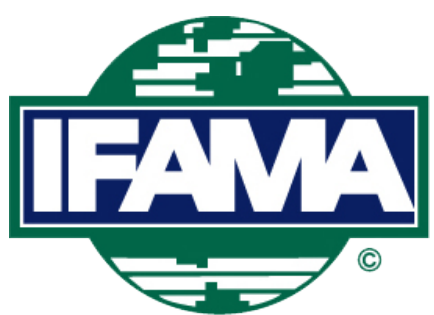

International Food and Agribusiness Management Review

Volume 24, Issue 2, 2021; DOI: 10.22434/IFAMR2020.0016

Received: 5 June 2019 / Accepted: 15 May 2020

Special track: European agrifood business in transition towards social responsibility

\title{
Innovation behavior of agri-food small and medium-sized enterprises: the case of Europe's emerging economies \\ RESEARCH ARTICLE
}

\author{
Gaukhar B. Kussainova ${ }^{\mathrm{a}}$, Sayed H. Saghaian ${ }^{\circledR b}$ and Michael R. Reed ${ }^{\mathrm{b}}$ \\ ${ }^{a}$ Master's student, ${ }^{b}$ Professor, Department of Agricultural Economics, University of \\ Kentucky, 400 Charles E. Barnhart Bldg., Lexington, KY 40546-0276, USA
}

\begin{abstract}
This paper examines the innovative behavior of agri-food firms located in Central and Eastern Europe. In the literature, empirical analyses on innovation activities of firms focus on various case studies from around the world. However, very few studies explore the innovation of small and medium sized enterprises from Central and Eastern Europe's agri-food sector. The analysis uses the logit estimation method and firm-level data, which are obtained from ERBD-World Bank Business Environment and Enterprise Performance Survey. Results suggest that firms that spent some proportion of their financial budget on research and development, had workforce training programs, and bought fixed assets are more likely to launch product, process, organizational, and marketing innovations.
\end{abstract}

Keywords: innovation drivers, Central and Eastern Europe, agri-food sector, firm-level data JEL code: O31, M21

(1)Corresponding author: ssaghaian@uky.edu 


\section{Introduction}

Innovation can be defined as the use of novel or ameliorated product, process, organizational or marketing practices in a firm's workplace organization, business operations or its relations with other external entities (OECD and Eurostat, 2005). Technological progress and innovation have always been an area of interest for human civilization from the use of fire in prehistoric times to the modern age's computers, cars, cell phones, satellites, etc.

Innovation is commonly split into four types: product, process, organizational and marketing innovation (OECD and Eurostat, 2005). According to the United Nations (UN) (2013), Joseph Schumpeter put forward the argument that technical advances and dynamic innovation activities mainly originate in large enterprises that have robust capacities in research and development (R\&D), even though Schumpeter acknowledged the role of new entrepreneurs in the development of a country's economy.

Innovation is a critical factor for both the advancement and development of the economy because it serves as a basis for productivity gains, new employment opportunities and new firms (OECD, 2015). In addition, innovation-based economies have a higher resilience, greater productivity, and more ability to adjust to changing circumstances. They also have a higher capability to support better standards of living (OECD, 2015). Kafetzopoulos et al. (2015) showed that Greek firms' process and product innovations directly and positively influence the firm's competitive advantage. Based on the empirical analysis of data on British small and medium-sized enterprises (SMEs), Laforet (2013) found that organizational innovativeness is associated with job environment, leadership position in the market, better business margins, and better productivity.

As reported by OECD (2009), entrepreneurs and SMEs are critical participants in a country's economy, and they are considered to be important engines of growth, income, innovation activities and jobs. Small and medium-sized enterprises are independent businesses that are not subsidiaries and that employ a smaller number of employees than some given level (OECD, 2006, 2009). In this study, the term 'R\&D' (in-house or through the use of external firm services) indicates that the firm systematically engages in creative work to accumulate knowledge (EBRD and World Bank, 2018b).

The objective of this article is to examine the driving forces of innovation activities by SMEs in Central and Eastern European countries by empirically analyzing data from firms that conduct their business in the agrifood sector. The following countries are considered in the empirical analysis: Albania, Armenia, Azerbaijan, Belarus, Bosnia and Herzegovina, Bulgaria, Croatia, the Czech Republic, Estonia, Georgia, Hungary, Latvia, and Lithuania, the Former Yugoslav Republic (FYR) of Macedonia, Moldova, Montenegro, Poland, Romania, Russia, Serbia, the Slovak Republic, Slovenia and Ukraine.

In the Central and Eastern European region, the agricultural sector plays a more crucial role as a part of the overall economy compared to developed countries (Klomp, 2014). As pointed out by Klomp (2014), from fifteen to twenty\% of Central and Eastern Europe's overall employment and gross domestic product, in comparison to the European Union's two to three\%, was traditionally represented by the agricultural sector (Table 1).

The contribution of this article to the literature on SME innovation is that this paper adds critical insight into the innovation drivers in Central and Eastern Europe's agri-food SME sector. The article is organized in the following way: The next section of the paper presents the literature review on innovation. Section 3 discusses the methodology and presents the empirical framework. Section 4 introduces the data and outlines the summary statistics. Section 5 reports the results and the conclusion is presented in Section 6. 
Table 1. Vegetable and fruit export values (in 1000 US\$) by year and rank in the Central and Eastern European Region (adapted from FAOSTAT, 2018).

\begin{tabular}{llrl}
\hline Country & Year & Value (1000 US\$) & Rank \\
\hline Poland & 2010 & $2,886,523$ & $1^{\text {st }}$ \\
\multirow{2}{*}{ Hungary } & 2013 & $4,198,735$ & $1^{\text {st }}$ \\
& 2010 & 715,636 & $2^{\text {nd }}$ \\
Lithuania & 2013 & 841,407 & $3^{\text {nd }}$ \\
& 2010 & 690,485 & $3^{\text {rd }}$ \\
Montenegro & 2013 & $1,256,197$ & $2^{\text {rd }}$ \\
& 2010 & 12,512 & $23^{\text {rd }}$ \\
\hline
\end{tabular}

\section{Literature review}

\subsection{Innovation studies}

Academic studies have focused on a broad variety of issues in the field of innovation analysis, including productivity (e.g. Friesenbichler and Peneder, 2016; Tevdovski et al., 2017) and economic factors (e.g. Ghazalian and Fakih, 2017). Friesenbichler and Peneder (2016) found that both indirect and direct exporting activities and an increase in the proportion of employees with higher education contribute to an increase in R\&D. Furthermore, Friesenbichler and Peneder (2016) highlighted that innovation and business competition simultaneously and independently influence the sampled firms' productivity using ERBD-World Bank Business Environment and Enterprise Performance Survey (BEEPS) V data. Tevdovski et al. (2017) analyzed productivity and innovation determinants of firms in three countries (Romania, Germany and Bulgaria). The authors found that product innovation positively influences workforce productivity in all sampled countries, whereas process innovation only has a positive influence on workforce productivity in two out of the three countries.

Another area of topic that has been investigated heavily is the drivers of innovation processes. For example, studies on enterprise innovation has been conducted in Australia (Bhattacharya and Bloch, 2004; Rogers, 2004), the Netherlands (Fortuin and Omta, 2009), Croatia (Božić and Mohnen, 2016), Italy (Capitanio et al., 2010; Ciliberti et al., 2016), India (Ali et al., 2017), the United Kingdom (UK) (Laforet and Tann, 2006), and Europe (Barata and Fontainha, 2017; Minarelli et al., 2015). Laforet and Tann (2006) highlighted that customer orientation, market anticipation, novel techniques of working and engagement of business leaders in new product and process development are determinants of manufacturing SMEs' innovation. They concluded that the leading challenges to SMEs include insufficient skills/knowledge, workforce training, financial constraints, networking, and consumer dependency.

Klonowski (2012) examined the innovation activities in Polish manufacturing SMEs using primary data and found that many SMEs have problems with commercialization. Rogers (2004) employed a probit approach to identify the drivers of innovation in Australia's firms. Barata and Fontainha (2017) explored drivers of construction industry's product and process innovation in Europe using the probit estimation.

Božić and Mohnen (2016) used probit and multivariate probit approaches to investigate the innovation drivers of Croatian manufacturing and service SMEs and found that in terms of non-technological innovativeness, service and manufacturing SME firms differ greatly. They postulated that [in-house] R\&D is a driver of product innovativeness for both manufacturing and service SME firms. Another result of the study was that service SMEs have a lower likelihood of launching technological innovations. They also found that manufacturing SME firms have a higher likelihood of being present in foreign market places, tend to be larger in size, and 
have greater gains from public assistance in R\&D. They also argued that public-provided funding is the critical driver of manufacturing SMEs' process innovation and service SMEs' product innovation.

\subsection{Innovation studies on the agri-food sector}

Some studies have been particularly interested in analyzing driving forces and obstacles for innovation activities in the agri-food sector. Using a sample of food processing firms from the Netherlands, Fortuin and Omta (2009) identified the chain's unequal distribution of power as a determinant of innovation. Capitanio et al. (2010) found that Italy's food firms are more focused on innovation if they sell more of their products/ services in targeted distribution channels. The findings of the study (Capitanio et al., 2010) underlined that process innovation is more associated with enterprise size and financial factors, whereas organizational aspects, like human capital's quality characteristics, are becoming more critical in a firm's novel product development.

Ciliberti et al. (2016) assessed the innovation determinants of Italian enterprises from industries such as pharmaceutical and food by employing a Community Innovation Survey (CIS). They stressed that the food industry's organizational capability and external drivers are beginning to play a more significant role in the innovation process. Another result of the paper was that internal R\&D has a larger importance for the pharmaceutical industry than for the food industry. Minarelli et al. (2015) assessed the factors of innovation activities in food and beverage firms from the SME sector located in several European Union countries, finding that process, product and market innovations are closely connected.

Some studies (e.g. Ali et al., 2017) did not find a significant influence of firm age on innovation. Rogers (2004) showed that $R \& D$ expenditure is positively related to innovation in the overall manufacturing sample. Expenditure on R\&D can be used as an indicator of innovation input, despite the fact that it may or may not result in innovation (Mateut, 2018). As discussed by Friesenbichler and Peneder (2016), an increase in R\&D expenditures raises the probability of success for innovations. Knowledge is a crucial element of both technological advances and innovation, and an important source of this knowledge is R\&D (Bhattacharya and Bloch, 2004).

Adult education and regular training can be critical in helping economies and enterprises achieve higher levels of competitiveness, easing workforce skill shortages and improving an ageing labor force's productivity levels (Kupets, 2018). Kupets (2018) showed that firms that have international contacts and firms that are innovative have a higher likelihood of investing in employee training. Moreover, in comparison to firms that have no training, Kupets (2018) found that a higher proportion of training enterprises have characteristics such as a satisfactory financial business performance, a common location in a home country's capital city and the presence of international contacts.

Additionally, in the food sector, Ciliberti et al. (2016) stressed that employee training pertaining to innovation activities is a significant determinant of innovation in CIS 2004 data, but not in CIS 2010 data. They indicated that there is a positive relationship between the acquisition of assets (i.e. software, equipment and machinery) and product and process innovation. Ali et al. (2017) employed formal training as one of the covariates in their work and found that certification and product innovation have a positive relationship, but training have no effect on the launch of product innovation.

Recently, Mateut (2018) indicated that exporters and those with access to foreign capital have significantly higher innovation. Ghazalian and Fakih (2017) asserted there is an association between exporting activities of the firm and a rise in R\&D activities. Barata and Fontainha (2017) documented that in comparison to regional and local-oriented businesses, international-oriented firms are more engaged in innovation.

Using BEEPS IV, Mateut (2018) posited that innovation and government-provided subsidies are positively related in their sample from emerging countries. Moreover, on average, firms that obtained subsidies had more 
innovation activity (Mateut, 2018). Ghazalian and Fakih (2017) found no significant association between R\&D activities and public subsidies. Using data from the entire sample, Tevdovski et al. (2017) found that funding from the European Union or national sources significantly affect R\&D engagement.

Hölscher et al. (2017) highlighted that newly admitted EU members (Central and Eastern European countries) and older members (Western European countries) do not differ to a large extent in their implementation of state support policies in industries such as finance and steel. They mentioned that without accounting for measures implemented during the financial crisis, members of the EU distributed fifty-four billion euros toward the assistance of domestic industries in the year 2013.

Moreover, one of the greatest hurdles that SMEs (notably, innovative firms) still face with respect to their establishment, business expansion, and survival is access to finance (OECD, 2009). Similarly, Beck and Demirguc-Kunt (2006) reported SME firms are more pressured by various obstacles (access to finance is one of these obstacles) than large enterprises. Another explanatory variable that was included in the model was location. Capitanio et al. (2010) showed that location is positively related to product innovativeness of food firms.

\section{Empirical model}

Following Ali et al. (2017), this study employs both the chi-square test and the logit models in its empirical investigation of innovation drivers. Hayashi (2000) stated that in the case when the outcome variable has two values (one and zero), this specific type of a qualitative response model is referred to as a binary response. As pointed out by Hayashi (2000), the logit regression is defined as:

$$
\left\{\begin{array}{l}
f\left(y_{t}=1 \mid x_{t} ; \theta_{0}\right)=\Lambda\left(x_{t}^{\prime} \theta_{0}\right), \\
f\left(y_{t}=0 \mid x_{t} ; \theta_{0}\right)=1-\Lambda\left(x_{t}^{\prime} \theta_{0}\right),
\end{array}\right.
$$

Where $y_{t}$ is the outcome variable, $x_{t}$ is a vector of independent variables, and $\theta_{0}$ is the true value of an estimated parameter. Here, $y_{t}$ is product, process, organizational or marketing innovation.

As stated by Hayashi (2000), in the logit regression, the cumulative density function is represented by $\Lambda$ :

$$
\Lambda(v) \equiv \frac{\exp (v)}{1+\exp (v)}
$$

According to Hayashi (2000), assuming that $\left\{y_{t}, x_{t}\right\}$ is independent and identically distributed, the log likelihood of the logit regression is defined as a summation of the log likelihood of each observation $t$ :

$$
Q_{n}(\theta)=\frac{1}{n} \sum_{t=1}^{n}\left\{y_{t} \log \Lambda\left(x_{t}^{\prime} \theta\right)+\left(1-y_{t}\right) \log \left[1-\Lambda\left(x_{t}^{\prime} \theta\right)\right]\right\}
$$

The methodology of this empirical analysis is based on the study by Ali et al. (2017). However, this study expands upon the work of Ali et al. (2017) in these ways: (1) this study looks at Central and Eastern Europe; (2) this study examines not just product innovation, but also process, organizational and marketing innovation; and (3) there are differences in the independent variables used.

To analyze the drivers of product, process, organizational and marketing innovation of agri-food firms in emerging economies, the following empirical model is employed:

$$
\begin{aligned}
y_{i}=\beta_{o}+ & \beta_{1} \text { Age }+\beta_{2} R \& D+\beta_{3} \text { Training } \\
& +\beta_{4} \text { Work Experience }+\beta_{5} \text { Fixed assets }+\beta_{6} \text { Certification } \\
& +\beta_{7} \text { Direct exporting }+\beta_{8} \text { Subsidies }+\beta_{9} \text { Government contract } \\
& +\beta_{10} \text { Location }+\beta_{11} \text { Access to finance }+\varepsilon
\end{aligned}
$$




\section{Data description}

The article's firm-level data on Central and Eastern European agri-food firms comes from the BEEPS V. The specific name of the dataset used is BEEPS V and MENA ES, 2012-2016 (EBRD and World Bank, 2018a). BEEPS's goal is to assess private-sector firms' opinions about their operating environment through the collection of firm-level data from a statistically representative sample (EBRD and World Bank, 2018a). The BEEPS V survey was conducted in thirty countries (in addition to Russia's thirty-seven regions) between 2011 and 2014 (EBRD and World Bank, 2018a).

The classification of firms as agri-food is based upon the works of Ali et al. (2017), the United Nations (UN, 2002) and specifically the survey's 'd1a2' variable. The following values of the survey's 'd1a2' variable were assumed to belong to the agri-food sector: 111, 122, 140, 1511-1593, 1600, 2010, 2412, 2421, 2921, 2925, 5100 (only 1 observation), 5121, 5122, 5211, 5220, and 5520 (see UN (2002) for code descriptions). In an effort to make the survey data useful, responses in BEEPS such as 'refused', 'does not apply,' and 'do not know' were dropped.

This study's description of variables are based on the BEEPS V's manual (EBRD and World Bank, 2018b). 'Product innovation' is a dummy variable that equals one if the firm has launched novel or refined services or products in the past three years, and 0 otherwise. 'Process innovation' is a dummy variable which represents whether the firm has introduced novel or refined supply or production techniques intended for the firm's services or products in the past three years. 'Organizational innovation' is a dummy variable which indicates whether the firm has launched novel or refined management or organizational changes in the past three years. 'Marketing innovation' is a dummy variable equals to one if the firm has launched novel or refined methods of marketing in the past three years.

In order to construct the 'age' variable, the paper uses the same approach as described by Friesenbichler and Peneder (2016). Using data from BEEPS V, Friesenbichler and Peneder (2016) stated that 2013 was the year the questionnaire was administrated in all countries, except in the case of Russia, where 2012 was the year of the questionnaire's administration. Friesenbichler and Peneder (2016) computed the 'age' variable in their study by subtracting the starting year of the firm's business operations (BEEPS V's ' $b 5$ ' variable) from the year of the questionnaire. BEEPS V's spending on R\&D is a 'yes', 'no' or 'don't know' question, and as mentioned earlier, the study's 'don't know' answers are dropped, thus, the 'R\&D' variable is a dummy, which is equal to one if the firm had expenditures on R\&D (external or in-house) in the past three years, and zero otherwise. 'Training' is a dummy variable equals one if the firm had training programs that were intended for the firm's full-time workforce in the past fiscal year, and 0 otherwise. 'Work experience' is a continuous variable which indicates the top manager's years of work experience in the industry. The 'fixed assets' dummy variable equals one if the firm bought fixed assets (i.e. vehicles, buildings, land, equipment or machinery) in the past fiscal year, and 0 otherwise.

'Certification' is a dummy variable equals one if the firm has an internationally accepted certification, and 0 otherwise. In this study, the 'certification' variable's 'otherwise' answer choice includes both 'no' and 'still in process' answers. Following Gërguri-Rashiti et al. (2017), a direct exporting variable is used in the model. The 'direct exporting variable' is the percentage of overall sales of the firm in the past fiscal year. The 'subsidies' variable is a dummy which indicates whether the firm has obtained subsidies from the government or the EU in the past three years. 'Government contract' is a dummy variable equal to one if the firm has tried or received a contract with the government in the past year, and 0 otherwise. 'Location' is a dummy variable that equals one if the firm operates in the country's capital, and 0 otherwise.

In the BEEPS V data, 'access to finance' is defined as whether the firm sees it as a hindrance to its business operations, and it is measured on a Likert scale from 0 ('no' hindrance) to 4 ('very severe' hindrance). Here, 'access to finance' is a dummy variable that is equal to one if access to finance is a 'very severe' or 'major' hindrance and zero if it is 'moderate', 'minor' or not a hindrance to the firm's business operations. 


\subsection{Summary statistics}

Table 2 reports summary statistics of agri-food firms under study. The average firm age in the full sample is 14 , with the minimum age of 1 and the maximum age of 149. However, in the case of SMEs, the average age of firms is 13 , with the minimum age of 1 and the maximum age of 118. The smallest and the largest average age of agri-food firms in the overall sample are in Albania (9 years), and Belarus (23 years), respectively (Figure 1). From Table 2, in both samples, top managers' work experience in the industry ranges from 1 to 60 years, with an average of 15 years. The average value of direct exporting as a part of overall annual sales

Table 2. Summary statistics for agri-food firms. ${ }^{1}$

\begin{tabular}{|c|c|c|c|c|c|c|c|c|}
\hline \multirow[t]{2}{*}{ Variable } & \multicolumn{4}{|c|}{ All $($ Obs. $=2,237)$} & \multicolumn{4}{|c|}{ SMEs $($ Obs.=1,942) } \\
\hline & Mean & SD & Min. & Max. & Mean & SD & Min. & Max. \\
\hline Product innovation & 0.238 & 0.426 & 0 & 1 & 0.223 & 0.417 & 0 & 1 \\
\hline Process innovation & 0.198 & 0.399 & 0 & 1 & 0.181 & 0.385 & 0 & 1 \\
\hline Organizational innovation & 0.206 & 0.405 & 0 & 1 & 0.183 & 0.387 & 0 & 1 \\
\hline Marketing innovation & 0.247 & 0.431 & 0 & 1 & 0.227 & 0.419 & 0 & 1 \\
\hline Age (years) & 14.798 & 12.670 & 1 & 149 & 13.638 & 9.462 & 1 & 118 \\
\hline $\mathrm{R} \& \mathrm{D}$ & 0.094 & 0.292 & 0 & 1 & 0.080 & 0.271 & 0 & 1 \\
\hline Training & 0.340 & 0.474 & 0 & 1 & 0.305 & 0.461 & 0 & 1 \\
\hline Work experience (years) & 15.533 & 9.180 & 1 & 60 & 15.508 & 9.041 & 1 & 60 \\
\hline Fixed assets & 0.397 & 0.489 & 0 & 1 & 0.364 & 0.481 & 0 & 1 \\
\hline Certifications & 0.193 & 0.395 & 0 & 1 & 0.166 & 0.372 & 0 & 1 \\
\hline Direct exporting (\%) & 3.614 & 14.601 & 0 & 100 & 2.640 & 12.648 & 0 & 100 \\
\hline Subsidies & 0.094 & 0.292 & 0 & 1 & 0.079 & 0.270 & 0 & 1 \\
\hline Government contract & 0.099 & 0.299 & 0 & 1 & 0.090 & 0.286 & 0 & 1 \\
\hline Location & 0.186 & 0.389 & 0 & 1 & 0.186 & 0.389 & 0 & 1 \\
\hline Access to finance & 0.183 & 0.387 & 0 & 1 & 0.180 & 0.384 & 0 & 1 \\
\hline
\end{tabular}

${ }^{1} \mathrm{R} \& \mathrm{D}=$ research and development; SD = standard deviation; SMEs = small and medium-sized enterprises.

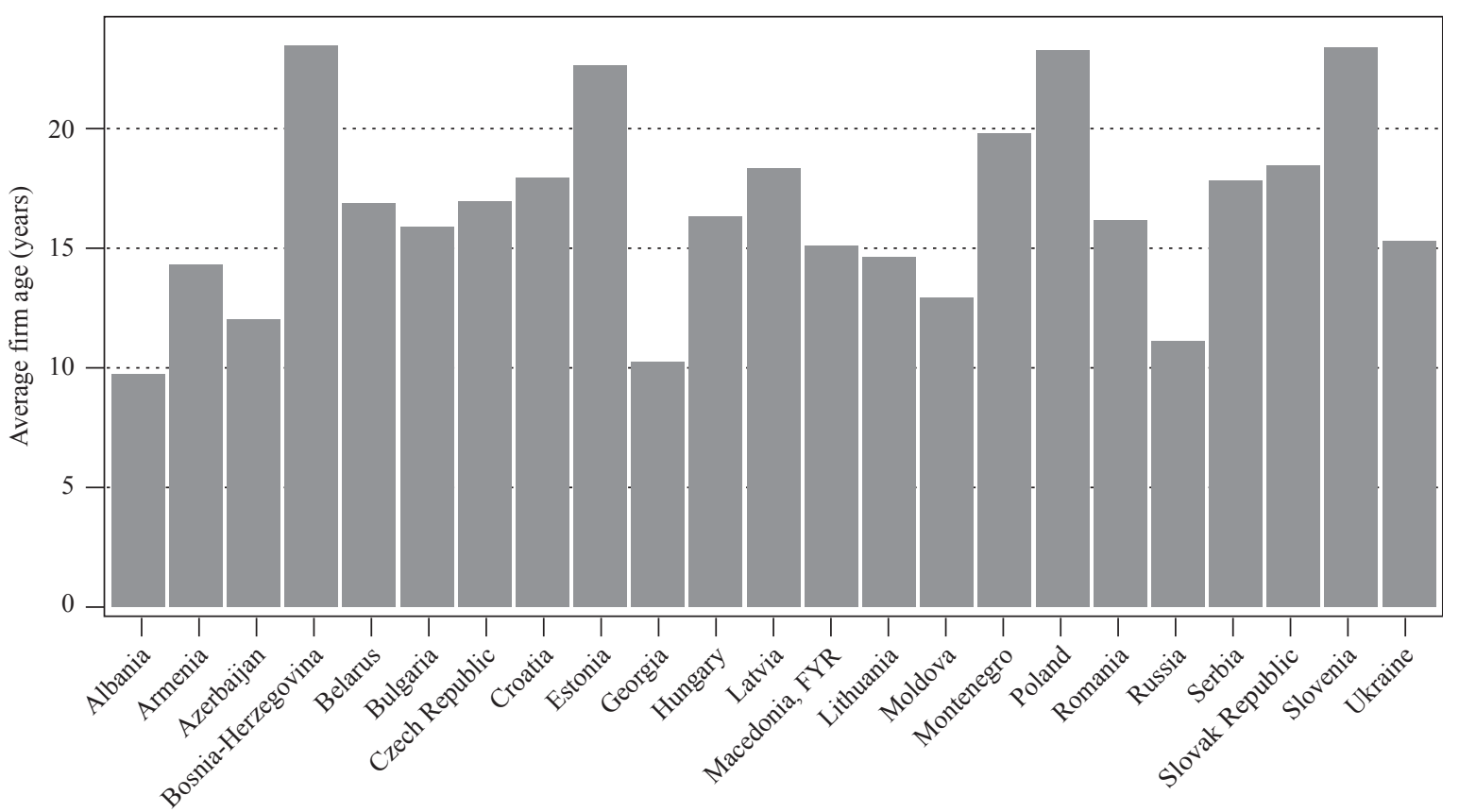

Figure 1. Average age of agri-food firms (full sample), by country (adapted from EBRD and World Bank, 2018a). 
of agri-food firms in the full sample is $3.6 \%$, and the mean value of direct exporting as a part of overall annual sales of agri-food firms in the SME sample is $2.6 \%$.

In the full sample, $9.4 \%$ of agri-food firms had expenditures on R\&D, while in the SME sample, $8 \%$ of agri-food firms had R\&D spending. 34\% of firms in the full sample and 30.5\% of SMEs had employee training programs. Moreover, approximately $40 \%$ of all firms and $36.4 \%$ of SMEs bought fixed assets. In the full sample, $19.3 \%$ of agri-food firms have certifications. $9.4 \%$ of firms in the full sample, and $7.9 \%$ of SMEs has obtained subsidies from the government or the EU. 9.9\% of firms in the full sample and $9 \%$ of SMEs have received or tried to receive a contact with the government. With regard to location, $18.6 \%$ of firms in both samples have business operations in their home country's capital city. Additionally, 18.3\% of firms in the full sample, and $18 \%$ of SMEs reported that access to finance was a severe/major hindrance to firms' business operations.

EBRD and the World Bank (2015) note that the core portion of BEEPS is answered by all firms regardless in which sectors these enterprises operate. As a result, it can be concluded that out of the total sample, 35.1\% are manufacturing firms (Figure 2). The distribution of business sizes of agri-food firms located in Central and Eastern European countries is plotted in Figure 3. Small firms account for the largest portion of the whole sample, followed by medium firms, large firms, and micro firms.

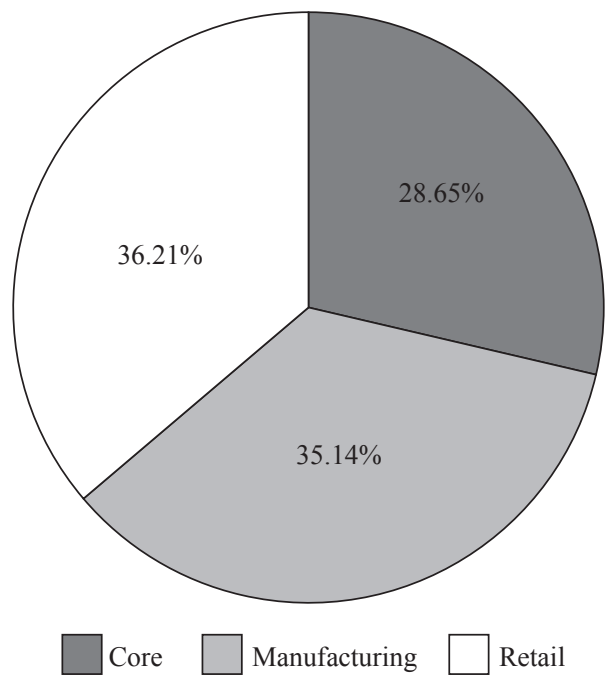

Figure 2. The Modules of BEEPS V (adapted from EBRD and World Bank, 2018a).

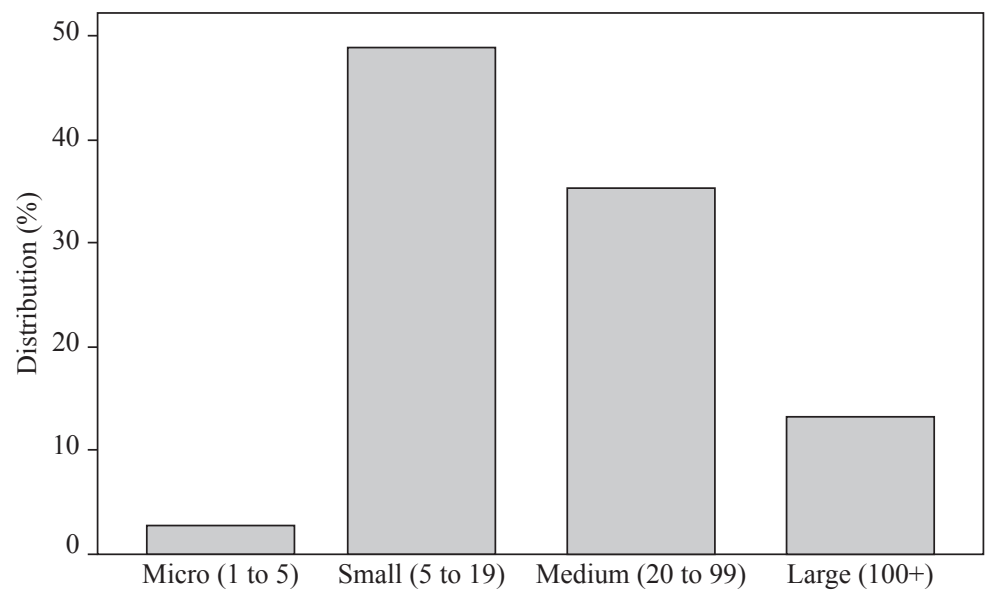

Figure 3. Distribution of firm sizes in the agri-food sector (adapted from EBRD and World Bank, 2018a). 


\section{Empirical results}

\subsection{Chi-Square and variance inflation factor tests}

Following Ali et al. (2017), this study utilizes the chi-square test on four types of innovation. As shown in Table 3, the implementation of product innovation is significantly different in large firms and SMEs (chisquare $=17.736, P=0.000$ ), which is in line with Ali et al. (2017). Large agri-food firms are more engaged in product innovation than SMEs.

The estimation results show the implementation of process (chi-square $=26.098, P=0.000$ ), organizational (chi-square $=46.640, P=0.000$ ) and marketing innovations (chi-square $=32.292, P=0.000$ ) is significantly different in large firms and SMEs. It turns out that large firms are more engaged in the launch of process, organizational and marketing innovations than SMEs.

The logit model estimates were checked for multicollinearity (Table 4). The variance inflation factor (VIF) test results show that independent variables do not seem to have a multicollinearity issue (all of the VIFs are less than 2.0). Table 5 reports the results of the logit model, where product, process, organizational and marketing innovations are outcome variables. Table 6 presents the marginal effects pertaining to the abovementioned logit model.

\subsection{Product innovation}

The logit model for product innovation with the SME sample had a Pseudo $\mathrm{R}^{2}$ of 0.13 , and the full sample's Pseudo $\mathrm{R}^{2}$ is 0.14 (Table 5). The first model (SMEs) has a lower Akaike Information Criterion (AIC) value than the second model (full sample), which is an indication that the first model has a better fit. $79.66 \%$ of the observations in the SME sample were correctly predicted, and $79.17 \%$ of the responses in the full sample were correctly predicted.

Table 3. Chi-square test: innovation types. ${ }^{1}$

\begin{tabular}{|c|c|c|c|c|c|}
\hline & \multicolumn{2}{|c|}{ Large firms } & \multicolumn{2}{|l|}{ SMEs } & \multirow{2}{*}{$\begin{array}{l}x^{2}(\mathrm{df}) \\
P \text {-value }\end{array}$} \\
\hline & Frequency & $\%$ & Frequency & $\%$ & \\
\hline \multicolumn{6}{|c|}{ Product innovation } \\
\hline No & 196 & 66.44 & 1,508 & 77.65 & $17.736^{* * *}$ \\
\hline Yes & 99 & 33.56 & 434 & 22.35 & 0.000 \\
\hline Total & 295 & 100 & 1,942 & 100 & \\
\hline \multicolumn{6}{|c|}{ Process innovation } \\
\hline No & 204 & 69.15 & 1,590 & 81.87 & $26.098 * * *$ \\
\hline Yes & 91 & 30.85 & 352 & 18.13 & 0.000 \\
\hline Total & 295 & 100 & 1,942 & 100 & \\
\hline \multicolumn{6}{|c|}{ Organizational innovation } \\
\hline No & 190 & 64.41 & 1,586 & 81.67 & $46.640 * * *$ \\
\hline Yes & 105 & 35.59 & 356 & 18.33 & 0.000 \\
\hline Total & 295 & 100 & 1,942 & 100 & \\
\hline \multicolumn{6}{|c|}{ Marketing innovation } \\
\hline No & 183 & 62.03 & 1,502 & 77.34 & $32.292 * * *$ \\
\hline Yes & 112 & 37.97 & 440 & 22.66 & 0.000 \\
\hline Total & 295 & 100 & 1,942 & 100 & \\
\hline
\end{tabular}

$1 * * *$ is significant at $1 \%$. SMEs $=$ small and medium-sized enterprises. 
Table 4. The variance inflation factor (VIF) test results for the logit models. ${ }^{1}$

\begin{tabular}{lll}
\hline Independent variables & VIF (SMEs) & VIF (AII) \\
\hline Age & 1.2 & 1.13 \\
R\&D & 1.1 & 1.14 \\
Training & 1.12 & 1.16 \\
Experience & 1.2 & 1.11 \\
Fixed assets & 1.1 & 1.14 \\
Certifications & 1.1 & 1.14 \\
Direct exporting & 1.04 & 1.07 \\
Subsidies & 1.07 & 1.1 \\
Government contract & 1.05 & 1.05 \\
Location & 1.02 & 1.02 \\
Access to finance & 1.01 & 1.01 \\
\hline
\end{tabular}

${ }^{1} \mathrm{R} \& \mathrm{D}=$ research and development; SMEs = small and medium-sized enterprises.

Table 5. Logit estimates on innovation types using the sample of agri-food firms. ${ }^{1,2}$

\begin{tabular}{|c|c|c|c|c|c|c|c|c|}
\hline & \multicolumn{2}{|c|}{ Product innovation } & \multicolumn{2}{|c|}{ Process innovation } & \multicolumn{2}{|c|}{$\begin{array}{l}\text { Organizational } \\
\text { innovation }\end{array}$} & \multicolumn{2}{|c|}{ Marketing innovation } \\
\hline & SMEs & All & SMEs & All & SMEs & All & SMEs & All \\
\hline \multirow[t]{2}{*}{ Age } & $0.014 * *$ & 0.007 & 0.010 & 0.007 & 0.007 & $0.008 *$ & 0.007 & $0.008^{*}$ \\
\hline & $(0.006)$ & $(0.004)$ & $(0.007)$ & $(0.004)$ & $(0.007)$ & $(0.004)$ & $(0.006)$ & $(0.004)$ \\
\hline \multirow[t]{2}{*}{$\mathrm{R} \& \mathrm{D}$} & $1.472 * * *$ & $1.620 * * *$ & $1.659 * * *$ & $1.733 * * *$ & $2.192 * * *$ & $2.086 * * *$ & $1.901 * * *$ & $1.853 * * *$ \\
\hline & $(0.191)$ & $(0.169)$ & $(0.192)$ & $(0.169)$ & $(0.200)$ & $(0.176)$ & $(0.198)$ & $(0.175)$ \\
\hline \multirow[t]{2}{*}{ Training } & $0.508 * * *$ & $0.446 * * *$ & $0.804 * * *$ & $0.721 * * *$ & $1.054 * * *$ & $1.038 * * *$ & $0.689 * * *$ & $0.720 * * *$ \\
\hline & $(0.126)$ & $(0.116)$ & $(0.134)$ & $(0.124)$ & $(0.136)$ & $(0.123)$ & $(0.125)$ & $(0.115)$ \\
\hline \multirow[t]{2}{*}{ Work experience } & 0.003 & 0.002 & -0.004 & -0.005 & -0.007 & -0.007 & -0.007 & -0.008 \\
\hline & $(0.007)$ & $(0.006)$ & $(0.008)$ & $(0.007)$ & $(0.008)$ & $(0.007)$ & $(0.007)$ & $(0.006)$ \\
\hline \multirow[t]{2}{*}{ Fixed assets } & $0.802 * * *$ & $0.724 * * *$ & $0.662 * * *$ & $0.630 * * *$ & $0.623 * * *$ & $0.654 * * *$ & $0.845 * * *$ & $0.868 * * *$ \\
\hline & $(0.122)$ & $(0.113)$ & $(0.133)$ & $(0.123)$ & $(0.136)$ & $(0.124)$ & $(0.122)$ & $(0.113)$ \\
\hline \multirow[t]{2}{*}{ Certifications } & $0.538 * * *$ & $0.459 * * *$ & $0.481 * * *$ & $0.412 * * *$ & 0.183 & 0.148 & 0.201 & 0.108 \\
\hline & $(0.148)$ & $(0.133)$ & $(0.162)$ & $(0.143)$ & $(0.171)$ & $(0.148)$ & $(0.158)$ & $(0.139)$ \\
\hline \multirow[t]{2}{*}{ Direct exporting } & $0.008 * *$ & 0.005 & 0.002 & $0.006^{*}$ & -0.000 & 0.000 & -0.006 & -0.002 \\
\hline & $(0.004)$ & $(0.003)$ & $(0.005)$ & $(0.004)$ & $(0.005)$ & $(0.004)$ & $(0.005)$ & $(0.004)$ \\
\hline \multirow[t]{2}{*}{ Subsidies } & $0.351 *$ & $0.376 * *$ & 0.145 & 0.046 & 0.119 & 0.115 & 0.304 & 0.224 \\
\hline & $(0.198)$ & $(0.172)$ & $(0.216)$ & $(0.186)$ & $(0.224)$ & $(0.189)$ & $(0.204)$ & $(0.177)$ \\
\hline \multirow[t]{2}{*}{ Government contract } & $0.457 * *$ & $0.307 *$ & $0.724 * * *$ & $0.682 * * *$ & 0.236 & 0.199 & 0.240 & $0.302 *$ \\
\hline & $(0.185)$ & $(0.167)$ & $(0.190)$ & $(0.169)$ & $(0.206)$ & $(0.180)$ & $(0.192)$ & $(0.168)$ \\
\hline \multirow[t]{2}{*}{ Location } & 0.188 & 0.110 & -0.289 & -0.212 & 0.041 & 0.180 & -0.191 & -0.107 \\
\hline & $(0.152)$ & $(0.140)$ & $(0.180)$ & $(0.160)$ & $(0.174)$ & $(0.153)$ & $(0.161)$ & $(0.146)$ \\
\hline \multirow[t]{2}{*}{ Access to finance } & 0.049 & 0.040 & 0.007 & 0.066 & 0.168 & 0.170 & -0.000 & 0.033 \\
\hline & $(0.152)$ & $(0.139)$ & $(0.166)$ & $(0.149)$ & $(0.165)$ & $(0.148)$ & $(0.154)$ & $(0.139)$ \\
\hline \multirow[t]{2}{*}{ Constant } & $-2.433 * * *$ & $-2.237 * * *$ & $-2.536 * * *$ & $-2.462 * * *$ & $-2.555 * * *$ & $-2.540 * * *$ & $-2.066 * * *$ & $-2.091 * * *$ \\
\hline & $(0.154)$ & $(0.136)$ & $(0.166)$ & $(0.148)$ & $(0.169)$ & $(0.150)$ & $(0.149)$ & $(0.134)$ \\
\hline Pseudo $\mathrm{R}^{2}$ & 0.132 & 0.137 & 0.153 & 0.164 & 0.180 & 0.191 & 0.141 & 0.157 \\
\hline Log likelihood & -895.506 & $-1,060.209$ & -778.234 & -930.895 & -758.905 & -920.852 & -892.297 & -1053.223 \\
\hline $\operatorname{LR} x^{2}(11)$ & $272.47 * * *$ & $336.13 * * *$ & $281.8 * * *$ & $364.76 * * *$ & $332.47 * * *$ & $434.29 * * *$ & $293.73 * * *$ & $393.39 * * *$ \\
\hline AIC & $1,815.012$ & $2,144.419$ & $1,580.468$ & $1,885.790$ & $1,541.811$ & $1,865.705$ & $1,808.595$ & $2,130.445$ \\
\hline Correctly classified & $79.66 \%$ & $79.17 \%$ & $83.16 \%$ & $82.61 \%$ & $84.81 \%$ & $83.24 \%$ & $80.84 \%$ & $79.88 \%$ \\
\hline Observations & 1,942 & 2,237 & 1,942 & 2,237 & 1,942 & 2,237 & 1,942 & 2,237 \\
\hline
\end{tabular}

$1 *, * *, * * *$ are significant at the 10,5 , and $1 \%$, respectively; the standard errors of the logit are presented in parentheses.

${ }^{2} \mathrm{AIC}=$ Akaike information criterion; $\mathrm{LR}=$ likelihood ratio; $\mathrm{R} \& \mathrm{D}=$ research and development; $\mathrm{SMEs}=$ small and medium-sized enterprises. 
Table 6. Logit marginal effects (at the mean) on innovation types using the sample of agri-food firms. ${ }^{1,2}$

\begin{tabular}{|c|c|c|c|c|c|c|c|c|}
\hline & \multicolumn{2}{|c|}{ Product innovation } & \multicolumn{2}{|c|}{ Process innovation } & \multicolumn{2}{|c|}{$\begin{array}{l}\text { Organizational } \\
\text { innovation }\end{array}$} & \multicolumn{2}{|c|}{ Marketing innovation } \\
\hline & $\begin{array}{l}\text { SMEs } \\
\text { Marginal } \\
\text { effect }\end{array}$ & $\begin{array}{l}\text { All } \\
\text { Marginal } \\
\text { effect }\end{array}$ & $\begin{array}{l}\text { SMEs } \\
\text { Marginal } \\
\text { effect }\end{array}$ & $\begin{array}{l}\text { All } \\
\text { Marginal } \\
\text { effect }\end{array}$ & $\begin{array}{l}\text { SMEs } \\
\text { Marginal } \\
\text { effect }\end{array}$ & $\begin{array}{l}\text { All } \\
\text { Marginal } \\
\text { effect }\end{array}$ & $\begin{array}{l}\text { SMEs } \\
\text { Marginal } \\
\text { effect }\end{array}$ & $\begin{array}{l}\text { All } \\
\text { Marginal } \\
\text { effect }\end{array}$ \\
\hline \multirow[t]{2}{*}{ Age } & $0.002 * *$ & 0.001 & 0.001 & 0.001 & 0.001 & $0.001 *$ & 0.001 & $0.001 *$ \\
\hline & $(0.001)$ & $(0.001)$ & $(0.001)$ & $(0.001)$ & $(0.001)$ & $(0.001)$ & $(0.001)$ & $(0.001)$ \\
\hline \multirow[t]{2}{*}{ R\&D } & $0.232 * * *$ & $0.271 * * *$ & $0.210 * * *$ & $0.238 * * *$ & $0.277 * * *$ & $0.292 * * *$ & $0.303 * * *$ & $0.315 * * *$ \\
\hline & $(0.031)$ & $(0.029)$ & $(0.026)$ & $(0.025)$ & $(0.028)$ & $(0.027)$ & $(0.033)$ & $(0.031)$ \\
\hline \multirow[t]{2}{*}{ Training } & $0.080 * * *$ & $0.074 * * *$ & $0.102 * * *$ & $0.099 * * *$ & $0.133 * * *$ & $0.146^{* * *}$ & $0.110 * * *$ & $0.122 * * *$ \\
\hline & $(0.020)$ & $(0.019)$ & $(0.017)$ & $(0.017)$ & $(0.017)$ & $(0.017)$ & $(0.020)$ & $(0.019)$ \\
\hline \multirow[t]{2}{*}{ Work experience } & 0.000 & 0.000 & -0.001 & -0.001 & -0.001 & -0.001 & -0.001 & -0.001 \\
\hline & $(0.001)$ & $(0.001)$ & $(0.001)$ & $(0.001)$ & $(0.001)$ & $(0.001)$ & $(0.001)$ & $(0.001)$ \\
\hline \multirow[t]{2}{*}{ Fixed assets } & $0.126 * * *$ & $0.121 * * *$ & $0.084 * * *$ & $0.087 * * *$ & $0.079 * * *$ & $0.092 * * *$ & $0.135 * * *$ & $0.148 * * *$ \\
\hline & $(0.019)$ & $(0.019)$ & $(0.017)$ & $(0.017)$ & $(0.017)$ & $(0.017)$ & $(0.019)$ & $(0.019)$ \\
\hline \multirow[t]{2}{*}{ Certifications } & $0.085 * * *$ & $0.077 * * *$ & $0.061 * * *$ & $0.057 * * *$ & 0.023 & 0.021 & 0.032 & 0.018 \\
\hline & $(0.023)$ & $(0.022)$ & $(0.020)$ & $(0.020)$ & $(0.022)$ & $(0.021)$ & $(0.025)$ & $(0.024)$ \\
\hline \multirow[t]{2}{*}{ Direct exporting } & $0.001 * *$ & 0.001 & 0.000 & $0.001 *$ & -0.000 & 0.000 & -0.001 & -0.000 \\
\hline & $(0.001)$ & $(0.001)$ & $(0.001)$ & $(0.000)$ & $(0.001)$ & $(0.001)$ & $(0.001)$ & $(0.001)$ \\
\hline \multirow[t]{2}{*}{ Subsidies } & $0.055^{*}$ & $0.063 * *$ & 0.018 & 0.006 & 0.015 & 0.016 & 0.048 & 0.038 \\
\hline & $(0.031)$ & $(0.029)$ & $(0.027)$ & $(0.026)$ & $(0.028)$ & $(0.027)$ & $(0.032)$ & $(0.030)$ \\
\hline \multirow{2}{*}{$\begin{array}{l}\text { Government } \\
\text { contract }\end{array}$} & $0.072 * *$ & $0.051^{*}$ & $0.092 * * *$ & $0.094 * * *$ & 0.030 & 0.028 & 0.038 & $0.051 *$ \\
\hline & $(0.029)$ & $(0.028)$ & $(0.024)$ & $(0.023)$ & $(0.026)$ & $(0.025)$ & $(0.031)$ & $(0.029)$ \\
\hline \multirow[t]{2}{*}{ Location } & 0.030 & 0.018 & -0.037 & -0.029 & 0.005 & 0.025 & -0.030 & -0.018 \\
\hline & $(0.024)$ & $(0.023)$ & $(0.023)$ & $(0.022)$ & $(0.022)$ & $(0.021)$ & $(0.026)$ & $(0.025)$ \\
\hline \multirow[t]{2}{*}{ Access to finance } & 0.008 & 0.007 & 0.001 & 0.009 & 0.021 & 0.024 & -0.000 & 0.006 \\
\hline & $(0.024)$ & $(0.023)$ & $(0.021)$ & $(0.020)$ & $(0.021)$ & $(0.021)$ & $(0.024)$ & $(0.024)$ \\
\hline Observations & 1,942 & 2,237 & 1,942 & 2,237 & 1,942 & 2,237 & 1,942 & 2,237 \\
\hline
\end{tabular}

$1 *, * *, * * *$ are significant at the 10,5 , and $1 \%$, respectively; the standard errors of the logit are presented in parentheses.

${ }^{2} \mathrm{R} \& \mathrm{D}=$ research and development; SMEs $=$ small and medium-sized enterprises.

For SME firms, the estimated coefficients of age and direct exporting are significant at the 5\% level, but in the case of the full sample, the coefficients are insignificant. It can be concluded that for every $1 \%$ increase in direct exporting as a proportion in overall sales, the agri-food SMEs are $0.1 \%$ more likely to introduce product innovation.

In both samples, the coefficients of R\&D have positive signs, and they are statistically significant, suggesting that compared to firms with no R\&D spending, firms with $R \& D$ expenditures are more likely to introduce some form of product innovation. In the SME sample, the agri-food firms with formal training are $8 \%$ more likely to have product innovation compared to the agri-food firms with no training programs available for their workforce. There is a positive correlation between the acquisition of fixed assets by the agri-food firms in Central and Eastern European countries and product innovation. Moreover, subsidies and product innovation are positively linked, and a contract with the government positively affects the introduction of product innovation in the agri-food firms.

Another variable that is significant in both samples is the variable certifications. In the full sample, having internationally accepted certifications has a positive and statistically significant impact on the product innovation of agri-food firms, which is in line with the work of Ali et al. (2017). For the SME sample, the 
agri-food firms that have certifications are $8.5 \%$ more likely to have product innovation compared to the agri-food SMEs that do not certifications. For both samples, the coefficients associated with work experience, location and access to finance are not significant, meaning that these variables do not have a statistically significant influence on the launch of product innovation by the surveyed agri-food firms.

\subsection{Process innovation}

The Pseudo $\mathrm{R}^{2}$ for the logit model for process innovation is 0.153 for SMEs and 0.164 for the entire sample (Table 5). The first model's Akaike information criterion (AIC) value is lower than the second model's AIC value, which suggests that the former model has a better fit than the latter model. Yet there wasn't much difference in their predictions: $83.16 \%$ of observations were correctly classified in the first model and $82.61 \%$ in the second model. In both models, the estimated coefficients of firm age, work experience of top managers, the presence of subsidies, a firm's location, and a firm's access to finance are not statistically significant.

Both models had significant positive coefficients for the firm's R\&D expenditures, training programs, purchase of fixed assets, presence of certifications, and a contract with the government. For the full sample, a 1\% increase in the proportion of direct exports in overall sales increases the probability of process innovation by $0.1 \%$.

\subsection{Organizational innovation}

The logit model for organizational innovation correctly classified $84.8 \%$ of the observations for SMEs and $83.2 \%$ for all firms (Table 5). The SME model has a much better fit (AIC value of 1,541.811 vs 1,865.705) and a Pseudo $\mathrm{R}^{2}$ of 0.18 vs 0.19 .

Both models have three common drivers of organizational innovation $-\mathrm{R} \& \mathrm{D}$, purchase of fixed assets, and formal training. The estimated coefficients of these variables are positive and significant. This could be explained by the fact that in order to make some changes in the organizational structure, agri-food firms may need to invest in training of their full-time employees. Moreover, for the full sample, older agri-food firms are more likely to have organizational innovation.

\subsection{Marketing innovation}

The last logit involves marketing innovation (Table 5), where $80.84 \%$ of the observations were correctly classified in the SME sample, while $79.88 \%$ of the observations were correctly classified in the full sample. The SME model has a better fit than the full model (these the AIC statistics). The explanatory power of the logit model has a Pseudo $\mathrm{R}^{2}$ of 0.14 and 0.15 , respectively, for the SMEs and full sample.

In the full sample, five determinants of marketing innovation can be identified: firm age, $R \& D$, training of the workforce, purchase of fixed assets and a contract with the government. In both samples, the estimated coefficients of R\&D, employee training, and fixed assets are highly statistically significant. This indicates that agri-food firms with R\&D expenditures, training opportunities, and those that purchased some fixed assets are more likely to have marketing innovation compared to firms with no R\&D spending, training programs, and those firms that did not acquire fixed assets.

Furthermore, the R\&D variable has the most influence on the marketing innovation in both samples. In the full sample, older agri-food firms have a higher likelihood of marketing innovation. This could be due to the fact that older firms may have more experience in implementing innovative marketing techniques compared to younger counterparts.

To summarize, in the case of SME firms only, there is no relationship between organizational and marketing innovations and firm age, which is inconsistent with the results of Lefebvre et al. (2015), who found a 
negative and significant linkage between age and organizational innovation and marketing innovation. Product, process, organizational and marketing innovation in both samples have three common drivers: (1) R\&D expenditures; (2) the presence of training programs for their workforce; and (3) the purchase of fixed assets. Furthermore, the estimated coefficients of managerial work experience, firm location and a firm's access to financial resources are not significant in product, process, organizational, or marketing innovation models in either sample. That is, factors such as work experiences of top managers in the industry and the location of agri-food firms in a capital city do not have an influence on four types of innovation.

\section{Conclusions}

The global food sector must innovate in order to address the challenges of population growth and climate change, and improve food quality and quantity. This study provides key insights on how food and agribusiness small and medium scale enterprises in the Central and Eastern Europe are responding to the changing business environment and competing with large firms through innovation. An understanding of product innovation adopted by food and agribusiness SMEs may help in designing a better policy framework for SMEs. An analysis of factors affecting the level of adoption of innovations may help the firms to better formulate their business strategy and enable them to complete in the emerging market environment efficiently and effectively.

By employing a logit estimation and using BEEPS V data, this study broadens the understanding about the innovation factors of SMEs that operate in Central and Eastern Europe's agri-food sector. This study contributes to the limited number of empirical studies in the academic literature on innovation of SMEs, looking at factors influencing the innovation processes of agri-food SMEs located in the emerging economies of Europe. The main result of this analysis is that firms that spent some proportion of their financial budget on $\mathrm{R} \& \mathrm{D}$, had workforce training programs and acquired fixed assets are more likely to launch product, process, organizational, and marketing innovations. Results of the study are important for stakeholders, academic researchers, and policymakers since the research identifies factors that impact the innovation activities of Central and Eastern Europe's agri-food SMEs, and could help determine areas that need further improvements and support.

The implication of the study is that the attention of agribusiness managers and policymakers should be devoted to acquiring more fixed assets, workforce training and R\&D in the agri-food sector. The main challenge is to access sufficient financial and technological resources that allow investment in these technologies in order to upgrade and modernize the agri-food SMEs. Furthermore, Governments and policymakers should be aware of these effective innovation drivers, including subsidy considerations in order to promote and help in the innovation processes and efforts. There should be continuing monitoring of the innovation processes and innovation activities of the agri-food sector, given the fast changes in information processing, distribution channels, technologies and methods of production, and storage of products.

Food and agribusiness SMEs can uplift the agricultural economy, generate employment and strengthen export earnings, but face stiff competition from giant global multinational companies with significant resources for R\&D to innovate. This is clear from the analysis that innovation is more prominent in large enterprises compared to SMEs. However, SMEs are more diversified, implying that SMEs have better potential for innovation, if proper policy support can be provided to SMEs. By improving the quality of products through innovation, SMEs will certainly be able to compete more effectivity with the large firms. There is an urgent need for building the business capacity of SMEs in order to enable them to strengthen their capabilities to achieve competitive advantage through innovation.

One of the caveats of the paper is that causal statements cannot be made since the dataset is cross-sectional (Barata and Fontainha, 2017; Lefebvre et al., 2015). Another limitation of the study is the small sample size. Furthermore, because of the nature of BEEP V data, it was not possible to include a lot of continuous variables in the estimated logit model. It is suggested that future studies include more quantitative variables with the use of a large sample of primary data if available. 


\section{Acknowledgement}

Saghaian acknowledges support from the USDA, National Institute of Food and Agriculture, Hatch project No. KY004052, under accession number 1012994.

\section{References}

Ali, J., M. Reed and S. Saghaian. 2017. Determinants of product innovation in food and agribusiness small and medium enterprises (SMEs) in India: evidence from enterprise survey data. Paper presented at the IFAMA World Conference, Miami, FL, USA.

Barata, J.M. and E. Fontainha. 2017. Determinants of innovation in European construction firms. Technological \& Economic Development of Economy 23(6): 915-936.

Beck, T. and A. Demirguc-Kunt. 2006. Small and medium-size enterprises: access to finance as a growth constraint. Journal of Banking \& Finance 30(11): 2931-2943.

Bhattacharya, M. and H. Bloch. 2004. Determinants of innovation. Small Business Economics 22(2): 155-162.

Božić, L. and P. Mohnen. 2016. Determinants of innovation in Croatian SMEs-comparison of service and manufacturing firms. Market-Tržište 28(1): 7-27.

Capitanio, F., A. Coppola and S. Pascucci. 2010. Product and process innovation in the Italian food industry. Agribusiness 26(4): 503-518.

Ciliberti, S., L. Carraresi and S. Bröring. 2016. Drivers of innovation in Italy: food versus pharmaceutical industry. British Food Journal 118(6): 1292-1316.

European Bank for Reconstruction and Development (EBRD) and the World Bank. 2015. The business environment and enterprise performance survey (BEEPS) V: a report on methodology and observations October 2015. EBRD and World Bank, London / Washington, UK, USA. Available at: https://tinyurl. com/y82qxozz

European Bank for Reconstruction and Development (EBRD) and the World Bank. 2018a. EBRD-World Bank business environment and enterprise performance survey (BEEPS) (data and about). EBRD and World Bank, London / Washington, UK, USA.

European Bank for Reconstruction and Development (EBRD) and the World Bank. 2018b. Enterprise survey core module (2012). EBRD and World Bank, London / Washington, UK, USA.

Food and Agriculture Organization of the United Nations (FAOSTAT). 2018. Crops and livestock products. FAO, Rome, Italy. Available at: http://www.fao.org/faostat/en/\#data/TP

Fortuin, F.T.J.M. and S.W.F. Omta. 2009. Innovation drivers and barriers in food processing. British Food Journal 111(8): 839-851.

Friesenbichler, K. and M. Peneder. 2016. Innovation, competition and productivity. Economics of Transition 24(3): 535-580.

Gërguri-Rashiti, S., V. Ramadani, H. Abazi-Alili, L.P. Dana and V. Ratten. 2017. ICT, innovation and firm performance: the transition economies context. Thunderbird International Business Review 59(1): 93-102.

Ghazalian, P.L. and A. Fakih. 2017. R\&D and innovation in food processing firms in transition countries. Journal of Agricultural Economics 68(2): 427-450.

Hayashi, F. 2000. Econometrics. Princeton University Press, Princeton, New Jersey, USA.

Hölscher, J., N. Nulsch and J. Stephan. 2017. State aid in the new EU Member States. JCMS: Journal of Common Market Studies 55(4): 779-797.

Kafetzopoulos, D., K. Gotzamani and V. Gkana. 2015. Relationship between quality management, innovation and competitiveness. Evidence from Greek companies. Journal of Manufacturing Technology Management 26(8): 1177-1200.

Klomp, J. 2014. The political economy of agricultural liberalization in Central and Eastern Europe: an empirical analysis. Food Policy 49(1): 332-346.

Klonowski, D. 2012. Innovation propensity of the SME sector in emerging markets: evidence from Poland. Post-Communist Economies 24(1): 133-143. 
Kupets, O. 2018. Employer-provided training, innovation and skills in post-soviet countries. Economics of Transition 26(4): 725-768.

Laforet, S. 2013. Organizational innovation outcomes in SMEs: effects of age, size, and sector. Journal of World Business 48(4): 490-502.

Laforet, S. and J. Tann. 2006. Innovative characteristics of small manufacturing firms. Journal of Small Business and Enterprise Development 13(3): 363-380.

Lefebvre, V.M., H. De Steur and X. Gellynck. 2015. External sources for innovation in food SMEs. British Food Journal 117(1): 412-430.

Mateut, S. 2018. Subsidies, financial constraints and firm innovative activities in emerging economies. Small Business Economics 50(1): 131-162.

Minarelli, F., M. Raggi and D. Viaggi. 2015. Innovation in European food SMEs: determinants and links between types. Bio-based and Applied Economics 4(1): 33-53.

Organization for Economic Cooperation and Development (OECD). 2006. The SME financing gap. Vol. I. Theory and evidence. OECD, Paris, France, $136 \mathrm{pp}$.

Organization for Economic Cooperation and Development (OECD). 2009. The impact of the global crisis on SME and entrepreneurship financing and policy responses. OECD, Paris, France. Available at: http://www.oecd.org/cfe/smes/43183090.pdf

Organization for Economic Cooperation and Development (OECD). 2015. OECD innovation strategy 2015: an agenda for policy action. OECD, Paris, France. Available at: https://tinyurl.com/y4xvlaq5

Organization for Economic Cooperation and Development (OECD) and Statistical Office of the European Communities (Eurostat). 2005. Oslo manual: guidelines for collecting and interpreting innovation data, $3^{\text {rd }}$ edition. OECD, Paris, France. Available at: https://tinyurl.com/yxr2a93e

Rogers, M. 2004. Networks, firm size and innovation. Small Business Economics 22(2): 141-153.

Tevdovski, D., K. Tosevska-Trpcevska and E.M. Disoska. 2017. What is the role of innovation in productivity growth in Central and Eastern European countries? Economics of Transition 25(3): 527-551.

United Nations (UN). 2002. International standard industrial classification of all economic activities (ISIC) revision 3.1. UN, New York, NY, USA. Available at: https://tinyurl.com/yygcrmtm

United Nations (UN). 2013. Innovation policy for green technologies: guide for policymakers in the transition economies of Europe and Central Asia. UN, New York, NY, USA. Available at: https:/tinyurl.com/ y4b98a3k 
